2011-12-05

\title{
Integration of UPQC for Power Quality Improvement in Distributed Generation Network - A Review
}

\author{
Shafiuzzaman Khan Khadem \\ Trinity College Dublin, Ireland, skkhadem@gmail.com \\ Malabika Basu \\ Technological University Dublin, mbasu@tudublin.ie \\ Michael Conlon \\ Technological University Dublin, michael.conlon@tudublin.ie
}

Follow this and additional works at: https://arrow.tudublin.ie/eprccon

Part of the Controls and Control Theory Commons, and the Power and Energy Commons

\section{Recommended Citation}

S. K. Khadem, M. Basu and M. F. Conlon, Integration of UPQC for Power Quality Improvement in Distributed Generation Network - A Review, ISGT Europe 2011, Manchester UK, Dec 2011. doi:10.1109/ ISGTEurope.2011.6162813

This Article is brought to you for free and open access by the Electrical Power Research Centre at ARROW@TU Dublin. It has been accepted for inclusion in Conference Papers by an authorized administrator of ARROW@TU Dublin. For more information, please contact arrow.admin@tudublin.ie, aisling.coyne@tudublin.ie, gerard.connolly@tudublin.ie.

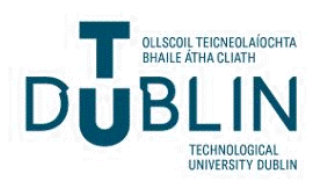




\title{
Integration of UPQC for Power Quality Improvement in Distributed Generation Network - A Review
}

\author{
Shafiuzzaman K Khadem, Student Member, IEEE, Malabika Basu, Member, IEEE and Michael F Conlon, Member, \\ IEEE
}

\begin{abstract}
In this paper a technical review of the integration of a Unified Power Quality Conditioner (UPQC) in a distributed generation network is presented. Although the primary task of UPQC is to minimize grid voltage and load current disturbances along with reactive and harmonic power compensation, additional functionalities such as compensation of voltage interruption and active power transfer to the load and grid have also been identified. Connection methodologies with their advantages and disadvantages are also described. Recent improvements in capacity expansion techniques and future trends for the application of UPQC in distributed modes are also identified.
\end{abstract}

\section{KEYWORDS}

Distribited Power Generation, Microgrid, Power Quality, Unified Power Quality Conditioner

\section{INTRODUCTION}

The increasing demand of Distributed Generation (DG) in recent years, to minimize the gap between the supply and load demand, is introducing some voltage and current disturbance and harmonics due to the generator types and the interfacing power electronics converters. Therefore, quality of power supply has become an important issue with the increasing demand of DG systems either connected to the grid through grid-tie inverters or work in isolated (microgrid) mode. The need for monitoring of power quality in low voltage distribution levels and ways to mitigate the problems are also increasing due to better customer service, reasonably priced meters, telecommunication development, network planning, operation and regulation requirements [1].

Implementation of Custom Power Devices (CPD) like UPQC in DG or microgrid systems to improve the power quality is gaining greater importance [2-6]. UPQC is the integration of series and shunt active filters, connected back-to-back on the dc side, sharing a common DC capacitor [3] as shown in Figure 1. The series component of the UPQC is responsible for mitigation of the supply side disturbances: voltage sags/swells, flicker, voltage unbalance and harmonics. It inserts voltages so as to maintain the load voltages at a desired

\footnotetext{
${ }^{1}$ S. K. Khadem, M. Basu and M. F. Conlon are with the School of Electrical Engineering Systems, Dublin Institute of Technology, Dublin 8, Ireland (email: skkhadem@gmail.com; mbasu@dit.ie; mbasu@ieee.org; michael.conlon@dit.ie;
}

level; balanced and distortion free. The shunt component is responsible for mitigating the current quality problems caused by the consumer: poor power factor, load harmonic currents, load unbalance etc. It injects currents in the ac system such that the source currents become balanced sinusoids and in phase with the source voltages.

This paper deals with the review of research work that has been completed so far on this issue. Emphasis has been given on incorporation techniques of UPQC in DG or microgrid system along with their advantages and disadvantages. More DGs such as Photovoltaic or Wind Energy Systems are now penetrating into the grid or microgrid. Again, numbers of nonlinear loads are also increasing. Therefore, current research on capacity enhancement techniques of UPQC to cope up with the expanding DG or microgrid system is also reviewed.

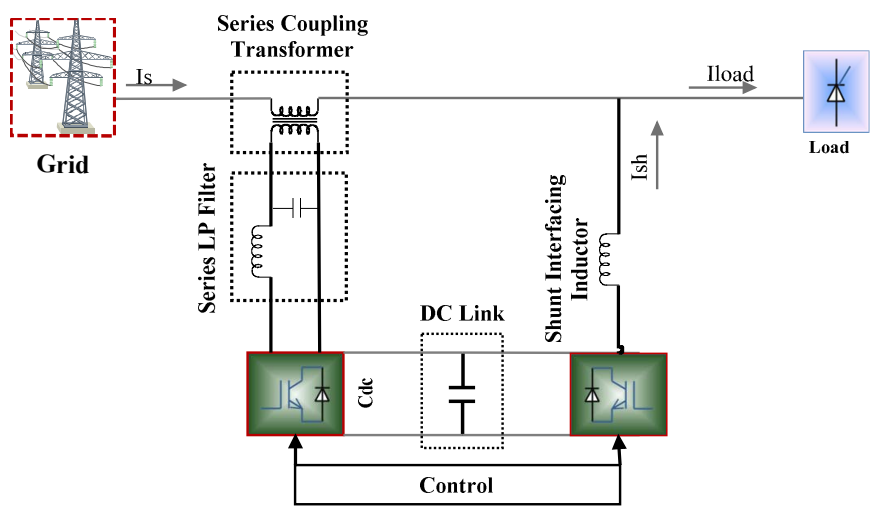

Fig. 1- System Configuration of UPQC

\section{INTEGRATION OF UPQC}

Recent reports [2-9] show that significant research and development has been carried out on the application of UPQC to DG integrated network. As the UPQC can compensate for almost all existing PQ problems in the transmission and distribution grid, placement of a UPQC in the distributed generation network can be multipurpose. As a part of integration of UPQC in DG systems, research has been done on the following two techniques: DC-Linked and Separated DG-UPQC systems. 


\section{A. $(D G-U P Q C)_{D C \text {-linked }}$}

A structure has been proposed in [2, 4-7], as shown in Figure 2, where DG sources are connected to a DC link in the UPQC as an energy source. This configuration works both in interconnected and islanded mode (shown in Figure 3). In Interconnected mode, DG provides power to the source and loads whereas in islanded mode DG (within its power rating) supplies the power to the load only. In Addition, UPQC has the ability to inject power using DG to sensitive loads during source voltage interruption. The advantage of this system is voltage interruption compensation and active power injection to the grid in addition to the other normal UPQC abilities. The system's functionality may be compromised if the DG resources are not sufficient during the voltage interruption conditions. Economical operation of the system can also be achieved by proper controlling of the active power transfer between the supply and DG source through a series APF [7]. The proposed system can also reduce the investment cost by nearly one fifth if the UPQC and DG are used separately [5].

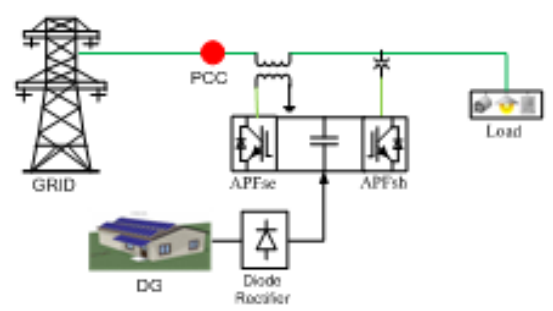

Fig 2 - UPQC with DG connected to the DC link

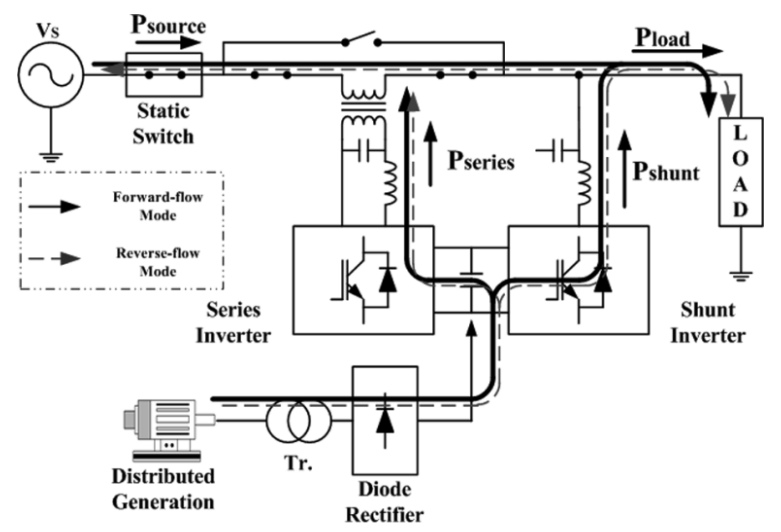

(a)

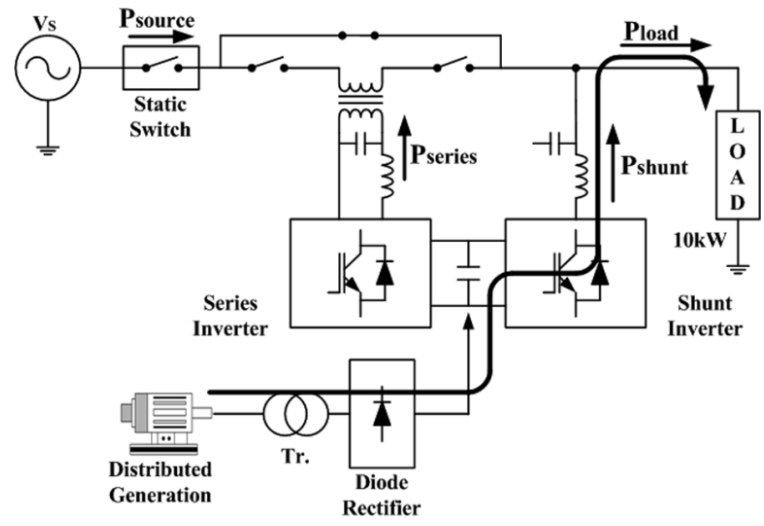

(b)

Fig. 3 - (DG-UPQC) DC-linked System operation concept. (a) Interconnected mode. (b) Islanding mode [2]

\section{B. $(U P Q C-D G)_{\text {Separated }}$}

A typical application of a UPQC might be to overcome the grid integration problems of the DG, such as the fixed-speed induction generator (FSIG) as investigated in [8] and shown in Figure 4. The FSIG fails to remain connected to the grid in the event of a grid voltage dip or line fault due to excessive reactive power requirement. The drop in voltage creates overspeeding of the turbine, which causes a protection trip. With the aid of the UPQC, this fault-ride-through capability is achieved, which greatly enhances system stability. Results show (Figure 5) that the UPQC is one of the best devices for the integration of wind energy system to the grid. In the case of a wind farm connected to a weak grid, UPQC can also be placed at the PCC to overcome voltage regulation problems [9]. In these separated systems, the series APF of the UPQC is placed near the DG side to conduct the voltage regulation by injecting the voltage in phase with PCC voltage. This type of UPQC is referred to as left shunt UPQC [3]. Based on the research study, in addition to the normal functionality of UPQC, some of the other advantages and disadvantages have been identified for the techniques which are given in Table 1.

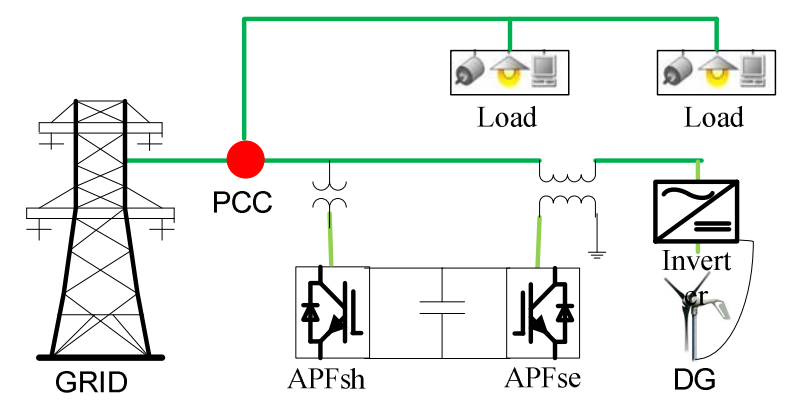

Fig 4 - Grid connected wind energy system with UPQC
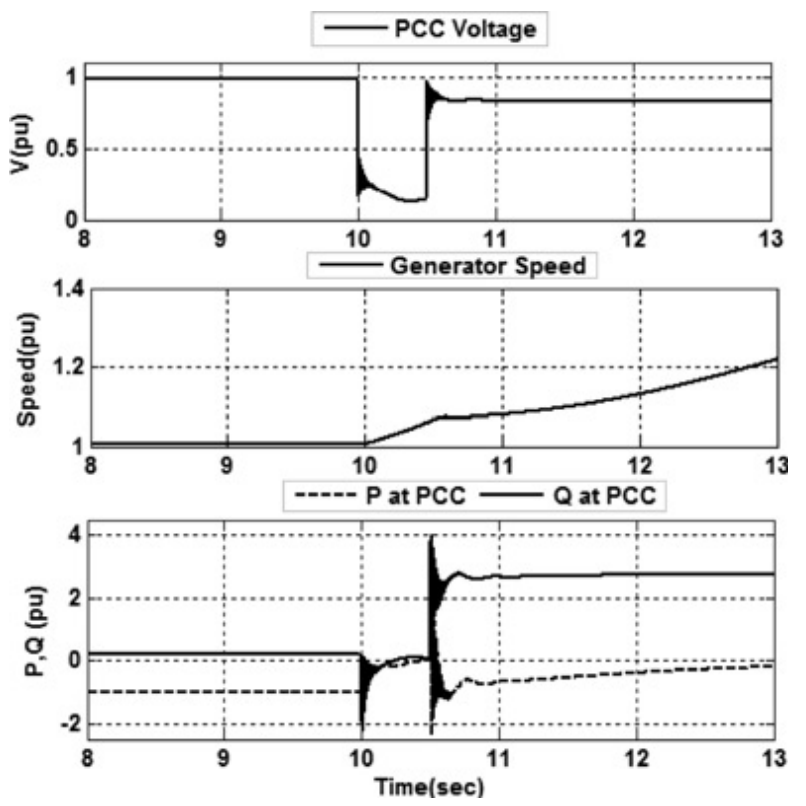

Fig 5- (a) Generator response to a three-phase fault without UPQC [9] 

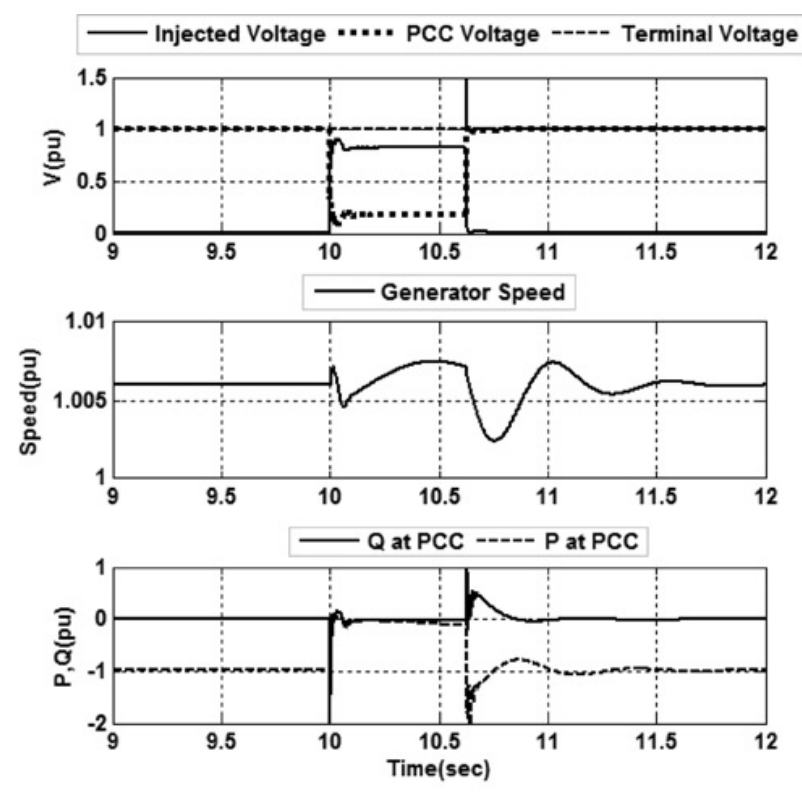

Fig 5 - (b) Generator response to a three-phase fault with UPQC [9]

TABLE 1

COMPARATIVE ANALYSIS OF INTEGRATION TECHNIQUES OF UPQC IN DG SYSTEM

\begin{tabular}{|l|l|l|}
\hline Technique & Advantages & Disadvantages \\
\hline (DG-UPQC) $)_{\text {DC linked }}$ & $\begin{array}{l}\text { i. Compensate the voltage } \\
\text { interruption } \\
\text { ii. Operation in islanding } \\
\text { mode - possible } \\
\text { iii. Active power transfer } \\
\text { during grid connected or } \\
\text { microgrid mode - } \\
\text { possible } \\
\text { iv. System cost for PQ } \\
\text { improvement - reduced } \\
\text { (remove DG Inverter) }\end{array}$ & $\begin{array}{l}\text { igh } \\
\text { ii. Capacity } \\
\text { enhancement in multi- } \\
\text { level or multi-module } \\
\text { mode - difficult }\end{array}$ \\
\hline (UPQC-DG) $)_{\text {Separated }}$ & $\begin{array}{l}\text { i. Capacity enhancement } \\
\text { in multi-level or multi- } \\
\text { module mode - easy } \\
\text { ii. Control - easy } \\
\text { iii. Active power transfer } \\
\text { during grid connected } \\
\text { mode - possible }\end{array}$ & $\begin{array}{l}\text { i. Voltage interruption - } \\
\text { may not be possible } \\
\text { ii. Operation in } \\
\text { islanding mode - may } \\
\text { not be possible } \\
\text { iii. System cost - high }\end{array}$ \\
\hline
\end{tabular}

\section{Cost Analysis}

In terms of required components, it is clear that the combined system does not require the grid connecting interfacing converter and thus the cost will be less. The purpose of the converter is already carried out by the shunt APF in the UPQC system. One the other hand in the separate system two complete units of UPQC and DG unit are required along with the interfacing converter. Therefore, there is no way to reduce the cost. A comparative analysis of investment cost and economical saving of separated and combined UPQC - DG (Wind Energy System) has been done in [5] based on the component cost found in [10]. It is found that, depending on the ratings, the combined system can reduce the cost up to one fifth of the separate system. Table 2 shows the details of this comparison.

TABLE 2

COMPARISON OF INVESTMENT COST AND ECONOMIC SAVING OF SEPARATE AND COMBINED UPQC AND DG (WIND SYSTEM) [2]

\begin{tabular}{|c|c|c|c|c|c|c|}
\hline \multirow[b]{3}{*}{ Equipment } & \multicolumn{6}{|c|}{ Rating (kVA) } \\
\hline & \multicolumn{2}{|l|}{15} & \multicolumn{2}{|l|}{150} & \multicolumn{2}{|l|}{1500} \\
\hline & Separate & Combined & Separate & Combined & Separate & Combined \\
\hline Wind turbine & 10515 & 10515 & 105004 & 105004 & 1050000 & 1050000 \\
\hline PWM rectifier & 5786 & 5786 & 47800 & 47800 & 394841 & 394841 \\
\hline Grid side inverter & 5786 & - & 47800 & . & 394841 & . \\
\hline Shunt inverter & 5786 & 5786 & 47800 & 47800 & 394841 & 394841 \\
\hline Series inverter & 5786 & 5786 & 47800 & 47800 & 394841 & 394841 \\
\hline Whole & 33662 & 27876 & 296202 & 248702 & 2629366 & 2234525 \\
\hline Economic saving (\%) & 20.7 & & 19.1 & & 17.6 & \\
\hline
\end{tabular}

\section{UPQC IN DOUBLE FEEDER DISTRIBUTION SYSTEM}

A new connection proposal for UPQC, as shown in Figure 6, to improve the power quality of two feeders in a distribution system has been made in [11] which is termed Interline UPQC (IUPQC). The purpose of the IUPQC is to hold the feeder voltages constant against voltage sag/swell and temporary interruption in either of the two feeders. It has been demonstrated that the IUPQC can absorb power from one feeder to hold the other feeder voltage constant in case of a voltage sag in the other source voltage. This UPQC can also be implemented in a Custom Power Park or Microgrid system. This can further be improved as a multi-converter based UPQC [12] where multiple VSI are connected back to back on the dc side.

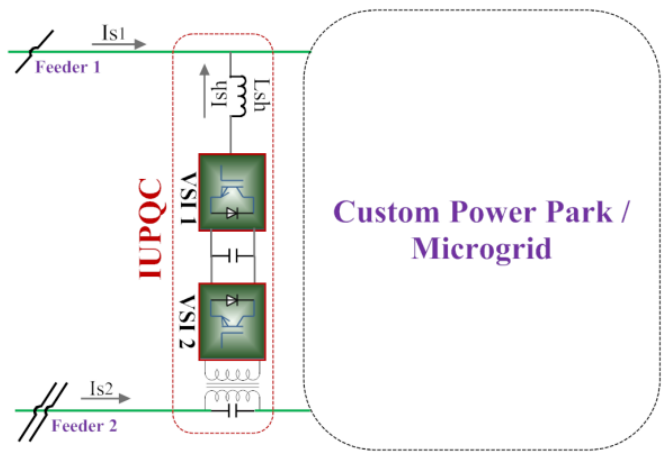

Fig 6 - (a) Typical IUPQC connected in a distribution system

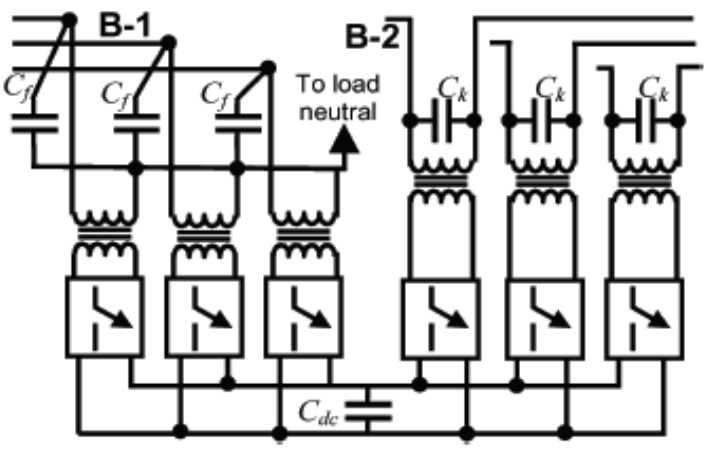

Fig 6 - (b) Internal Structure of IUPQC [11] 


\section{CAPACITY ENHANCEMENT OF UPQC}

In high power applications, the filtering task cannot be performed for the whole spectrum of harmonics by using a single converter due to the limitations on switching frequency and power rating of the semiconductor devices. Therefore, compensating the reactive harmonic components to improve the power quality of the DG integrated system as well as to avoid the large capacity centralised APF, parallel operation of multiple low power APF units are increasing. Like APF, UPQC can also be placed at the PCC or at a high voltage distribution line as a part of DG integrated network or in microgrid system to work both in interconnected or islanded mode. At this place, capacity enhancement is achieved by using Multi-level topologies to reach the higher power levels. These options are as follows:

i. Multi-level converter based UPQC

ii. Multi-module converter based UPQC

iii. Multi-module (power cell) unit based UPQC

A multi-level converter is proposed to increase the converter operation voltage, avoiding the series connection of switching elements. However, the multilevel converter is complex to form the output voltage and requires an excessive number of back-connection diodes or flying capacitors [13] or cascade converters [14]. A basic form of multi-level UPQC is shown in Figure 7.

A multi-module H-bridge UPQC can also be connected to the distribution system without series injection transformers. It has the flexibility in expanding the operation voltage by increasing the number of H-bridge modules [15], as shown in Figure 8 . Here each phase consists of several pairs of H-bridge modules isolated through a single-phase multiwinding transformer.

These Multi-module techniques [1318] allow the symmetrical distribution of the load power among the components of the topology, but the classical design procedure must be modified or refined to ensure the power cell components should be within its maximum ratings. Therefore, a new design procedure of UPQC with a feature of extending capacity based on a modular approach is presented in [19-20], shown in Figure 9, where H-bridge power cells are added in each single phase arrangement depending on the required compensating power. Some advantages and disadvantages are also outlined in Table3.

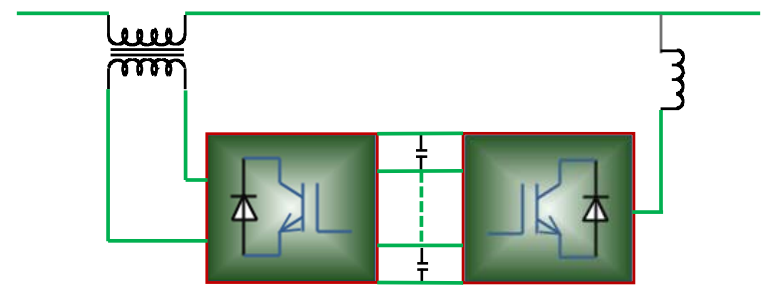

Fig. 7 - Multi level Converter based UPQC
TABLE 3

ADVANTAGES AND DISADVANTAGES FOR DIFFERENT TYPES OF UPQC IN CAPACITY EXPANSION.

\begin{tabular}{|c|c|c|}
\hline Type of UPQC & Advantages & Disadvantages \\
\hline $\begin{array}{l}\text { Multi-level } \\
\text { Converter based }\end{array}$ & $\begin{array}{l}\text { i. High voltage and } \\
\text { current can be achieved } \\
\text { ii. Can be developed in } \\
\text { different ways - diode } \\
\text { clamp / flying capacitor / } \\
\text { cascade inverter based }\end{array}$ & $\begin{array}{l}\text { i. Voltage unbalance } \\
\text { could occur between the } \\
\text { different levels } \\
\text { ii. Requires accessive } \\
\text { number of diode / flying } \\
\text { capacity / inverter } \\
\text { iii. Central control is } \\
\text { required and it is } \\
\text { complicated } \\
\text { iv. Conduction loss is } \\
\text { high } \\
\text { v. Capacity expansion is } \\
\text { difficult } \\
\text { vi. Centralized Approach }\end{array}$ \\
\hline $\begin{array}{l}\text { Multi-modular } \\
\text { transformer-less }\end{array}$ & $\begin{array}{l}\text { i. No series transformer is } \\
\text { required, thus reduces the } \\
\text { cost } \\
\text { ii. Capacity expansion is } \\
\text { easier than multi-level } \\
\text { converter } \\
\text { iii. Redundancy is } \\
\text { possible }\end{array}$ & $\begin{array}{l}\text { i. It requires high number } \\
\text { of switching devices to } \\
\text { enhance the capacity } \\
\text { ii. Central control is } \\
\text { required } \\
\text { iii. Conduction loss and } \\
\text { switching loss also high } \\
\text { iv. Due to symmetrical } \\
\text { distribution of the load } \\
\text { power among the H- } \\
\text { bridge inverters, modules } \\
\text { may not work at its } \\
\text { maximum rating }\end{array}$ \\
\hline $\begin{array}{l}\text { Multi-modular } \\
\text { (power cell) }\end{array}$ & $\begin{array}{l}\text { i. Single phase power cell } \\
\text { topology helps the unit to } \\
\text { work at its maximum } \\
\text { rating } \\
\text { ii. Capacity expansion is } \\
\text { easier } \\
\text { iii. Redundancy is } \\
\text { possible } \\
\text { iv. Both Central and } \\
\text { Distributed controls are } \\
\text { possible } \\
\text { v. Due to parallel mode } \\
\text { of operation, conduction } \\
\text { loss can be reduced }\end{array}$ & $\begin{array}{l}\text { i. Number of H-bridge } \\
\text { switching device } \\
\text { increases, thus increase } \\
\text { the switching loss } \\
\text { ii. Transformer for each } \\
\text { shunt part of the power } \\
\text { cell could increase the } \\
\text { loss as well as make the } \\
\text { system bulky } \\
\text { iii. Additional single } \\
\text { shunt unit may not be } \\
\text { included if only the } \\
\text { required compensating } \\
\text { current increases }\end{array}$ \\
\hline
\end{tabular}

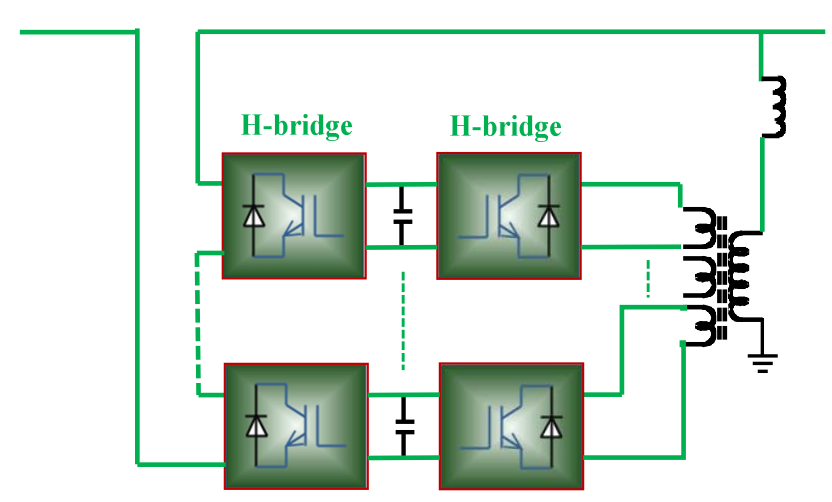

Fig 8 - Series transformer-less Multi-module H-bridge 


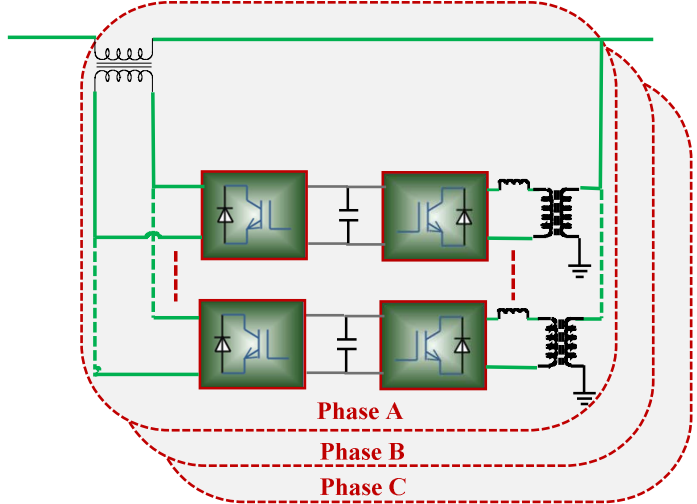

Fig 9 - Modular approach of UPQC based on power cells

\section{CONCLUSION}

- It is found that research in recent years has placed more emphasis on CPDs, especially on UPQC, and its application in DG or microgrid system.

- Single or modular type UPQC has been proposed to deal with power quality issues, with an addition to voltage interruption compensation, active power transfer, related to DG with integrated or microgrid mode.

- Capacity enhancement has been achieved using multi-level or multi-module and central control mode, however, the flexibility of UPQC to increase its capacity in future and to cope up with the increase load demand in low voltage distribution level has not been achieved.

- The economics for the capacity enhancement of UPQC should also be analysed.

\section{REFERENCE}

[1] P Jarventausta, S Repo, A Rautianinen, J Partanen, "Smart grid power system control in distributed generation environment", Annual Reviews in Control 34, 2010, pp. $277-286$

[2] B Han, B Bae, H Kim, S Baek, "Combined Operation of Unified Power Quality Conditioner with Distributed Generation", IEEE Trans Power Delivery, vol. 21(1), 2006, pp. $330-338$

[3] A Ghosh and G Ledwich, "Power quality enhancement using custom power devices", Kluwer Academic, 2002

[4] M Hosseinpour, Y Mohamadrezapour, S Torabzade, "Combined operation of Unifier Power Quality Conditioner and Photovoltaic Array", Journal of Applied Sciences, 2009, v-9(4), pp 680-688

[5] M Hosseinpour, A Yazdian, M Hohamadian, J Kazempour, "Desing and Simulation of UPQC to Improve Power Quality and Transfer Wind Energy to Grid", Jour of Applied Sciences, 2008, vol. 8(21), pp. 3770 - 3782.

[6] M A Emran, M Forghani, M Abedi, G B Gharehpetian, "Combined Operation of UPQC and Fuel Cell with Common DC Bus", ICREPQ 2008

[7] G S Reddy, "Feasibility analysis of DGSC-UPQC", IJRRAS, vol 4(1), 2010, pp. 32-47

[8] N G Jayanti, M Basu, M. F. Conlon and K. Gaughan "Rating requirements of the unified power quality conditioner to integrate the fixed speed induction generator-type wind generation to the grid", IET Renewable Power Generation, vol. 3(2), 2009, pp. 133-143

[9] M F Farias, P E Battaiotto, M G Cendoya, "Wind Farm to Weak-Grid connection using UPQC Custom Power Device", ICIT 2010, pp. 1745 - 1750

[10] J K Kaldellis, K A Kavadias, "Cost-benefit analysis of remote hybrid wind-diesel power stations: Case study Aegean Sea Islands", Energy Policy, vol 35, 2007, pp. 1525-1538

[11] A Kumar, "A Ghosh, Interline Unified Power Quality Conditioner", IEEE Trans Power Delivery, Vol. 22(1), 2007, pp. 364-372.
[12] H R Mohammadi, A Y Varjani, "Multiconverter Unified Power-Quality Conditioning System: MC-UPQC", IEEE Trans Power Delivery, Vol. 24(3), 2009, pp. 1679-1686.

[13] J Lai, F Z Peng, "Multilevel converters-a new breed of power converters", IEEE Trans Ind Appl, Vol. 32(3), 1996, pp. 509 - 517

[14] F Z Peng, J W McKeever and D J Adams, "A Power Line Conditioner Using Cascade Multilevel Inverters for Distribution Systems", IEEE Trans Ind Appl, Vol 34(6), 1998, pp. 1293 - 1298

[15] B. Han, B. Bae, S. Baek and G. Jang, "New Configuration of UPQC for Medium-Voltage Application", IEEE Trans Power Delivery, Vol. 21(3), 2006, pp. $1438-1444$

[16] B. Han, S. Baek, H. Kim, and G. Karady, "Dynamic characteristic analysis of SSSC based on multibridge inverter," IEEE Trans. Power Del. Vol. 17(2), 2002, pp. 623-629

[17] B.-M. Han and P. Mattavelli, "Operation analysis of novel UPFC based on 3-level half-bridge modules," in Proc. IEEE Bologna Power Tech Conf., Jun. 2003, vol. 4, pp. 307-312.

[18] J. Muñoz, J. Reyes, J. Espinoza, I. Rubilar, and L. Morán, “A novel multi-level three-phase UPQC topology based on full-bridge single-phase cells," in Proc. Conf. Rec. IEEE IECON, Nov. 2007, pp. 1787-1792.

[19] J A Munoz, J R Espinoza, "Design of a Modular UPQC Configuration Integrating a Components Economical Analysis", IEEE Trans Power Delivery, Vol. 24(4), 2009, pp. 1763-1772.

[20] J A Muñoz, J R Espinoza, C R A Morán, E Espinosa, P E Melín, D G Sbárbaro, "Design of a Discrete-Time Linear Control Strategy for a MultiCell UPQC", accepted for publication in IEEE Trans Ind Electr, 2011

\section{BIOGRAPHIES}

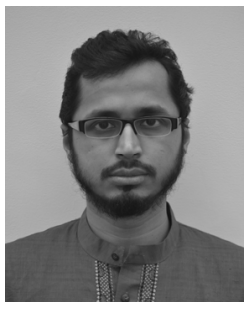

Shafiuzzaman K Khadem (S'09) received the B.Sc (hons) and M.Sc degrees in Applied Physics and Electronics from University of Dhaka, Bangladesh, in 1998 and 2000 respectively.

From 2001, he worked as a Research Associate in Renewable Energy Research Centre, University of Dhaka, Bangladesh for 6 years. In 2006, he joined as a Lecturer in the Electronics and Telecommunication Engineering Dept, University of Liberal Arts Bangladesh. From 2009, he started his $\mathrm{PhD}$ research on Power Quality improvement of DG Integrated Network using Unified Power Quality Conditioner.

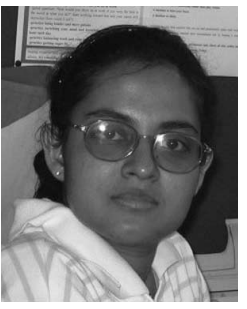

Malabika Basu (S'99-M'03) received the B.E. and M.E. degrees in electrical engineering from Bengal EngineeringCollege, Shibpur,Kolkata, India, in 1995 and 1997, respectively, and the Ph.D. degree in electrical engineering from Indian Institute of echnology, Kanpur, Uttar Pradesh, India, in 2003.

From 2001 to 2003, she was a Lecturer in Jadavpur University, Kolkata, West Bengal, India. From 2003 to 2006, she was Arnold F. Graves Postdoctoral Fellow at Dublin Institute of Technology, Dublin, Ireland, where she has been a Lecturer, since 2006. She has authored or coauthored more than 40 technical publications in various international journals and conference proceedings. Her current research interests include grid integration of renewable energy sources, power quality conditioners and power quality control and analysis, photovoltaics and wind energy conversion, and smart grid and microgrids.

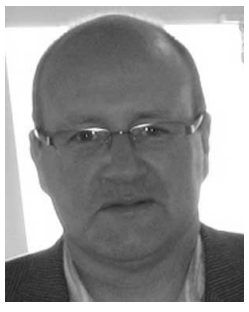

Michael F. Conlon (M'88) received the B.Sc. from Dublin Institute of Technology, Dublin, Ireland, in 1982, the M.Eng.Sc. degree by research and the Ph.D. degree from the University College, Galway, Ireland, in 1984 and 1987, respectively, all in electrical engineering.

He was at Monash University and Victorian Energy Networks Corporation, Melbourne, Vic., Australia. Currently, he is the Head of the Department of Control Engineering at the Dublin Institute of Technology, Dublin, Ireland. His research interests include power systems analysis and control applications, power systems economics, integration of wind energy in power networks, and quality of supply and reliability assessment. 